\title{
The Impact of Principal's Supervision and Leadership on the Performance of Teacher
}

\author{
Dewi Rusmala ${ }^{1 *)}$, Happy Fitria ${ }^{1}$, Yenny Puspita ${ }^{1}$ \\ ${ }^{1}$ Universitas PGRI Palembang, Indonesia \\ *Corresponding author. Email: yenny_puspitaa@yahoo.com
}

\begin{abstract}
The goals of this study were to understand: (1) the principal's leadership impact on performance of teacher, (2) the principal's supervision impact on performance of teacher, (3) the principal's leadership and supervision influence on performance of teacher. This research used a quantitative descriptive method with multiple correlations. The results of research were gathered by using questionnaire and documentation. The descriptive qualitative data were processed by SPSS version 26.0. We found that the number of $t$ or sig of leadership (X1) was 0.28 that is less than $a=0.05$. These results inferred that there was significant influence between leadership (X1) to teacher performance (Y). The result of $\mathrm{t}$ or sig. on principal supervision (X2) was 0.006 whose value is smaller than the value $\mathrm{a}=0.05$. This result inferred that there is a significant influence between principal supervision $(\mathrm{X} 2)$ with teacher performance (Y). The result of $\mathrm{F}$ was 27.134, the value is less than the accuracy value $\mathrm{a}=0.1(\mathrm{PV}<\mathrm{a})$ that means a significant influence between leadership (X1) and principal supervision (X2) to the teacher performance was observed.
\end{abstract}

Keywords: Leadership, Principal Supervision, Teacher Performance.

\section{INTRODUCTION}

Humans are social beings who cannot live alone. In social life in the community, people always interact with each other. People live in groups both in large groups and small groups. In organizations or human institutions are known as human resources (HR). Human resources are the most important thing owned by an Institution, including educational institutions or schools. The school is a formal Educational Institution that organizes teaching and learning activities to achieve its educational objectives. One of the implications is that the most important investment made by an Educational Institution is in the field of human resources. Therefore, for an Educational Institution to achieve maximum employment, fair and satisfactory treatment of human resources working in educational institutions, namely principals, educators, and education personnel, is required. Indonesia is lagging in the quality of education, both formal education, and informal education. The results were obtained after we compared with other countries [1]. The power of a leader in this case the headmaster is derived from his ability to influence others because of his nature and attitude, the breadth of his knowledge and experience, good at motivating relationships in his work environment. The headmaster must also have special skills so that he has the power, authority to direct and guide his subordinates to gain recognition and support from subordinates towards the achievement of certain objectives. The headmaster is a person who has advantages in terms of the ability to influence and move his subordinates. The spirit of work is at least influenced by the behavior of its leaders. Good leadership behavior, namely: 1) a leader must always think positively, always be enthusiastic, be able to understand and appreciate others, remain calm when in difficult or stressful situations, remain optimistic, do not swear against subordinates, explain their mistakes at the right time; 2) do not delay the answer or give a floating answer; 3) give orders in a request-for-help style; and 4) do not forget to give gifts or awards. Within the school environment, the headmaster is a very crucial part in determining the achievement of the educational objectives set by the school. A principal must be a determinant of direction, a change agent, a spokesperson and a coach.

A member of the organization carries out a certain responsibility, which must be done appropriately and clearly [2]. The ability of leadership skills and supervision in the briefing activities are important factors of effectiveness to improved teachers performance. If the Educational Institution can 
determine the behavior and techniques of effective leadership of the Institution, various behaviors and techniques will be learned. One of the tough challenges that often have to be faced by the headmaster is how the teacher is always willing and willing to exert his or her best abilities for the benefit of the group and the school [3]. Often we encounter principals who use their power thoroughly in giving orders to their teachers, regardless of ethics and manners.

This explains that there is a less harmonious relationship between the principal and teachers in the school environment due to the lack of openness. Thus, the success of the school can be seen as a representation of the success of a principal who implements or leads an Educational Institution. Teacher performance can be affected by many factors, such as lack of the headmaster's attention, lack of award support, unclear work direction. Weak regulations, absence of sanctions against violations of school rules, lack of clear mechanisms of work, not entering the office on time, undisciplined implementation of school rules, inadequate facilities and infrastructure available, supporting facilities available are incomplete, weak planning ability, organizing, implementation of activities.

Supervision is an activity carried out to improve and improve the quality of academic processes and achievements. Supervision is carried out for the improvement and development of the teaching and learning process in total. This means that the purpose of supervision is not only to improve the quality of teaching teachers but also to foster the growth of the teacher profession. In supervision, the headmaster acts as a supervisor. Principals can affect morale, teacher performance, security, job satisfaction, quality of worklife, and especially at the level of achievement of an organization. The headmaster has the burden of role and responsibility of fostering, monitoring, and improving the teaching and learning process in the classroom or the school because the headmaster is in charge of supervision activities. While the role of teachers in supervising is the teacher as the main role of the school education program that interacts directly with students in teaching and learning activities. And this is actually expected from supervision activities not only improving the professional quality of teachers but also supporting improvements to school administration and teacher administration problems. Quality learning that will improve the academic performance of students and teachers.

\section{METHODS}

This study uses a descriptive quantitative method by using multiple correlations that is a number that shows the direction and strong influence among two independent variables together with one dependent variable. Arikunto [4] said that a quantitative research is an approach used by students by measuring variable indicators to obtain the overview and conclusion of research. The research of quantitative is a study of problem-solving that is carefully planned, with a strictly structured design; data collection is controlled systematically and aimed at the preparation of the theory that is concluded inductively within the framework of empirical proof of the hypothesis. The quantitative study is an effort to measure the variables in the research, (variable X1 leadership, X2 supervision of the principal and variable $\mathrm{Y}$ teacher performance). To then look for the relationship between those variables.

This study was done in five high schools in West Bangka Regency, namely at SMAN 1 Mentok, SMAN 1 Jebus, SMAN 1 Simpang Teritip, SMAN 1 Kelapa, and SMA Bakti Jebus. This research lasted for 4 months, starting from July 2020 to October 2020.

The population in this research were teachers who taught at SMA Bangka Barat Regency. Population characteristics must be represented in the sample, meaning that the characteristics or circumstances of the population must be described in the sample. For samples with reference count the samples number is calculated using the equation Slovin as follows:

$$
n=N / 1+N(e)
$$

Description:

$$
\begin{array}{ll}
\mathrm{n} & \text { : sample data size } \\
\mathrm{N} & : \text { population } \\
\mathrm{e} & : \text { percentage of errors tolerated in sampling } \\
\mathrm{e} & : 10 \%(0.1)
\end{array}
$$

Here's how it's calculated. For the number of teachers 149 people the calculation is as follows:

$$
\begin{aligned}
& \mathrm{n}=149 / 1+149(0,1)^{2} \\
& \mathrm{n}=149 / 1+1,49 \\
& \mathrm{n}=149 / 2,49 \\
& \mathrm{n}=59,8
\end{aligned}
$$

Based on the calculation results obtained from the Slovin formula above, it is known that the amount of samples is 60 teachers from five high schools in West Bangka Regency, as follows:

Table 1. Population and Research samples

\begin{tabular}{clcc}
\hline No & \multicolumn{1}{c}{ Schools } & Teachers & Samples \\
\hline 1 & SMAN 1 Mentok & 36 & 15 \\
2 & SMAN 1 Simpang Teritip & 33 & 13 \\
3 & SMAN 1 Kelapa & 33 & 13 \\
4 & SMAN 1 Jebus & 27 & 10 \\
5 & SMA Swasta Bakti Jebus & 20 & 9 \\
\hline \multicolumn{2}{c}{ Total } & 149 & 60 \\
\hline
\end{tabular}


Data Collection Technique is a technique that is carried out to obtain the information needed to achieve research objectives, tools such as instruments. In this study, the data collection techniques that researchers use are Documentation and Questionnaires, as a data collection technique by giving a set of written statements or questions to respondents. Likert scale was used in compiling this poll. The Likert scale is used to regulate one's opinions and attitudes. On the Likert scale, respondents were proposed to fill questionnaires and requiring them to show their level of approval of a series of questions. Statements or questions used in this research were as variables that are defined by researchers. So with this Likert scale, researchers want to know how the leadership, supervision of the principal, and the performance of high school teachers in West Bangka Regency. In this study to collect data used instruments in the form of a list of questions (questioners) and interviews with selected respondents. The results of the questionnaire were then carried out a validity and reliability test with the alpha Cronbach technique through SPSS 26.0 program. According to Arikunto [5] documentation is investigating recorded matters such as documents, books, rules, diaries, and so on. Documentation is used to obtain data about teacher data at five high schools in Bangka Barat, which were sampled.

\section{RESULTS AND DISCUSSION}

\subsection{Normality Test}

Ghozali [6] said that the objective of the normality test is to discover if each variable is distributed normally or not. The test of normality is necessary to test whether other variable assuming that residual values follow the normal distribution. If this assumption is not true or invalid then the parametric statistic cannot be used. The purpose of the normality test is to find out whether the data obtained on bound variables and free variables distributed normally or not as prerequisite data must be normal before analyzing using the reverse test. A good regression model has near-normal data distribution. Normally distributed data in a regression model can be seen in the normal graph of the p-p plot, where if the points scattered around the diagonal spread follow the direction of the diagonal line, then the data can be said to be distributed normally.

\section{Table 2. The Test of Normality}

\begin{tabular}{|c|c|c|c|c|}
\hline \multicolumn{5}{|c|}{ One-Sample Kolmogorov-Smirnov Test } \\
\hline & & $\begin{array}{l}\text { KEPEMIMPI } \\
\text { NAN }\end{array}$ & $\begin{array}{c}\text { SUPERVIS } \\
1\end{array}$ & $\begin{array}{c}\text { KINERJ } \\
\text { A }\end{array}$ \\
\hline $\mathrm{N}$ & & 60 & 60 & 60 \\
\hline \multirow[t]{2}{*}{ Normal Parameters $\mathrm{s}^{\mathrm{a}, \mathrm{b}}$} & Mean & 130.42 & 132.95 & 131.05 \\
\hline & $\begin{array}{l}\text { Std. } \\
\text { Deviation }\end{array}$ & 9.671 & 10.898 & 10.510 \\
\hline \multirow{3}{*}{$\begin{array}{l}\text { Most Extreme } \\
\text { Differences }\end{array}$} & Absolute & 138 & .136 & 151 \\
\hline & Positive & .138 & .136 & 151 \\
\hline & Negative & -.107 & -.116 & -.089 \\
\hline Test Statistic & & 138 & .136 & .151 \\
\hline Asymp. Sig. (2-tailed) & & $.006^{\mathrm{c}}$ & $.008^{\mathrm{c}}$ & $.002^{\mathrm{c}}$ \\
\hline
\end{tabular}

Based on table 2. the normality test results above, it is obtained in part a that the test distribution is normal, stating that the distribution has been distributed normally.

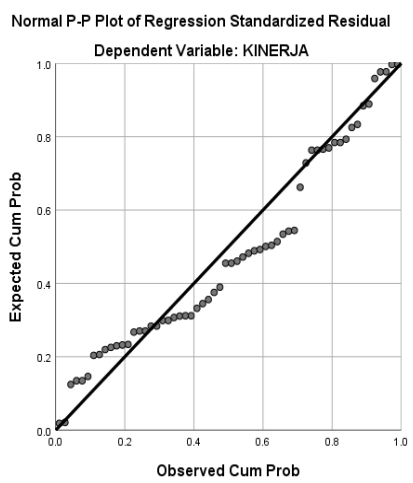

Figure 1. The diagram of P-P plot

\subsection{Double Correlation Statistical Analysis}

Calculation results for the summary model with the SPSS program can be seen in the table 3 .

Table 3. Model summary

\begin{tabular}{lc|r|r|r}
\hline Model & $\mathrm{R}$ & $\begin{array}{c}\mathrm{R} \\
\text { Square }\end{array}$ & $\begin{array}{c}\text { Adjusted R } \\
\text { Square }\end{array}$ & $\begin{array}{l}\text { Std. Error of } \\
\text { the Estimate }\end{array}$ \\
\hline 1 & $.698^{\mathrm{a}}$ & .488 & .470 & 7.653 \\
\hline
\end{tabular}

The result of double correlation analysis $(\mathrm{R})$ based on Model Summary output obtained the number $\mathrm{R}$ of 0.698 . Since the double correlation value is between $0.60-0.799$, it can be wrap up that there is a strong or significant influence between the leadership and the headmaster's division on teacher performance [7]. This is following the interpretation of the correlation coefficient as follows: $0.80-1.000=$ very strong; 0.60 $-0.799=$ strong; $0.40-0.599=$ medium; $0.20-0.399$ $=$ low; and $0.00-0.199=$ very low.

\subsection{Coefficient of Determination}

Based on table 2, the coefficient of Determination of $\mathrm{R}^{2}$ ( $\mathrm{R}$ Square) of 0.488 means that the leadership and supervision of the principal can influence the performance of teachers with a contribution of $48 \%$ while the remaining $52 \%$ is explained by factors not included in this study.

\subsection{Multiple Correlation Coefficients (Simultaneous Hypothesis)}

The table 4 indicates that the calculated value of $\mathrm{F}$ is 27.134. The number of significant $F$ is 0.000 where the value is less than the determination value of $0.1(\mathrm{Pv}<$ $1)$, this means that there is a significant influence between leadership (X1), and principal supervision (X2) on teacher performance $(\mathrm{Y})[8]$. 
Table 4. Anova model summary

\begin{tabular}{|c|c|c|c|c|c|c|}
\hline \multicolumn{2}{|c|}{ Model } & $\begin{array}{l}\text { Sum of } \\
\text { Squares }\end{array}$ & Df & $\begin{array}{l}\text { Mean } \\
\text { Square }\end{array}$ & $\mathrm{F}$ & $\begin{array}{c}\text { Sig } \\
\text {. }\end{array}$ \\
\hline \multirow[t]{3}{*}{1} & $\begin{array}{l}\text { Regres } \\
\text { sion }\end{array}$ & 3178.418 & 2 & $\begin{array}{r}1589.2 \\
09\end{array}$ & $\begin{array}{r}27.1 \\
34\end{array}$ & $\begin{array}{r}.00 \\
0^{\mathrm{b}}\end{array}$ \\
\hline & Residu & 3338.432 & 57 & 58.569 & & \\
\hline & Total & 6516.850 & 59 & & & \\
\hline
\end{tabular}

\subsection{Regression Coefficient (Partial Hypothesis)}

The amount of regression coefficient with analysis using multiple linear regression can be seen in the following figure.

Table 5. Regression coefficient

\begin{tabular}{|c|c|c|c|c|c|c|}
\hline \multirow{2}{*}{\multicolumn{2}{|c|}{ Model }} & \multicolumn{2}{|c|}{$\begin{array}{l}\text { Unstandard. } \\
\text { Coef. }\end{array}$} & \multirow{2}{*}{$\begin{array}{c}\text { Std } \\
\text { Coef } \\
\text { Beta } \\
\end{array}$} & \multirow[b]{2}{*}{$\mathrm{T}$} & \multirow[b]{2}{*}{ Sig. } \\
\hline & & B & $\begin{array}{l}\text { Std. } \\
\text { Error }\end{array}$ & & & \\
\hline 1 & (Constant) & $\begin{array}{r}31.2 \\
40\end{array}$ & 13.801 & & 2.264 & .027 \\
\hline & Leadership & .357 & .158 & .328 & 2.253 & .028 \\
\hline & Supervision & .401 & .141 & .416 & 2.851 & .006 \\
\hline
\end{tabular}

From the calculation results in the table above can be regression equation as follows:

$\mathrm{Y}=31,240+0.357+0.401+\mathrm{e}$.

From the regression equation above, it can be described as follows, a score of 31,240 means that the amount of teacher performance value when the principal's leadership and supervision score is equal to zero or constant is 31,240 . This value indicates that teacher performance is strongly influenced by the principal's leadership and supervision variables. While the leadership coefficient value is 0.357 , this value means that if the leadership rises by 1 unit of the score then the teacher's performance rises by 0.357 , if the principal supervision value (X2) is equal to zero. While the principal supervision coefficient value is 0.401 , this value means that if the headmaster's supervision rises by 1 unit of score units then the teacher's performance rises by 0.401 , if the leadership value (X1) is equal to zero.

Based on table 5 results, partial regression results are obtained as follows:

a) Value $t$ calculate or sig. $t$ leadership (X1) in the table above is 0.28 whose value is less than 0.05 . This means that there is a significant influence between leadership (X1) on teacher performance (Y) or it can be interpreted that Ho is rejected and $\mathrm{Ha}$ is accepted so that the hypothesis that "leadership affects the performance of high school teachers in West Bangka Regency" is significant. b) Value $t$ calculate or sig. $t$ supervision of the principal (X2) in the table above is 0.006 which is a value less than the value of $1=0.05$. This means that there is a significant influence between the supervision of the principal $(\mathrm{X} 2)$ on teacher performance $(\mathrm{Y})$ or it can be interpreted that Ho is rejected and Ha is accepted so that the hypothesis that "supervision of the principal affects the performance of teachers in high schools in West Bangka Regency" is significant.

In this discussion in the validity test in the study showed that the results of all statement items have a greater calculated $r$-value compared to the $r$ product moment table. This means that all items have shown validity so that further analysis can be continued. While reliability test obtained Crombach Alpha value for teacher performance $(\mathrm{Y})$ of $=0.965$. Crombach Alpha's value for leadership $(\mathrm{X} 1)$ is $=0.962$. Crombach Alpha for principal supervision $(\mathrm{X} 2)$ is $=0.965$. Thus, it can be said that the items in the test above have a high level of reliability [9].

The inferential analysis showed results that partially leadership variables have a significant influence on the performance of high school teachers in West Bangka District, where the partial test result (t-test) $t$ significance is worth 0.28 . And in the descriptive analysis also obtained results as many as more than $50 \%$ of respondents stated that the leadership of high school principals in Bangka Barat district is very good, but in some statements, there are still respondents who stated very well less than $50 \%$, this can be interpreted that the leadership of the principal has not been done thoroughly for each teacher. The results of the inferential analysis showed that partial supervision of the principal has a very significant influence on the performance of high school teachers in West Bangka Regency, where the partial test result (t-test) of $\mathrm{t}$ significance is worth 0.006 One of the supporting indicators for the headmaster to know the level of teacher development is supervision [10].

The results of the analysis above showed that the calculated $F$ value was 27.134 and the $F$ value of significant is 0.000 , where the value is less than the determination of $0.1(\mathrm{Pv}<1)$. This infers that there was a significant influence between leadership (X1) and supervision of the principal (X2) on teacher performance $(\mathrm{Y})$.

\section{CONCLUSIONS}

In summary, the $\mathrm{t}$ calculated or $\mathrm{Sig} \mathrm{t}$ value for leadership (X1) was 0.28 that means there is a significant correlation between leadership (X1) on teacher performance $(\mathrm{Y})$ and can be interpreted that $\mathrm{Ho}$ $\mathrm{Ha}$ is accepted and is rejected. Therefore, the hypothesis that "leadership affects the performance of teachers in 
high schools in West Bangka District" is significant or can be accepted.

The value of calculated $\mathrm{t}$ or Sig. for the principal supervision (X2) was 0.006 which is less than 0.05 . This infers that there wa a significant influence between the supervision of the principal (X2) on teacher performance (Y) or it can be interpreted that $\mathrm{Ho}$ is rejected and $\mathrm{Ha}$ is accepted so that the hypothesis that "supervision of the principal affects the performance of teachers in high schools in West Bangka Regency" is significant.

The calculated $\mathrm{F}$ value was 27.134 while the result of the sig $\mathrm{F}$ is 0.000 , where the number is less than the determination value of $0.1(\mathrm{Pv}<1)$. This infers that there is a significant influence between leadership (X1) and principal supervision $(\mathrm{X} 2)$ on teacher performance (Y).

\section{REFERENCES}

[1] Daryanto \& Karim, S. 2017. Pembelajaran Abad 21 Yogyakarta : Gava Media.

[2] Fattah, H. 2019. Kepuasan Kerja dan Kinerja Pegawai. Palembang: Elmatera.

[3] Tokan Ile, R. Manajemen Penelitian Guru. 2016. Jakarta. PT. Grasindo.

[4] Arikunto, S. 2013. Prosedur Penelitian Suatu Pendekatan Praktik Edisi Revisi. Jakarta: Rineka Cipta.

[5] Ghozali, Imam. 2013. Aplikasi Analisis Multivariate dengan program SPSS. Semarang: Badan Penerbit Universitas Diponegoro.

[6] Gatot Suradji \& Engelbertus Martono. 2014. Ilmu dan Seni Kepemimpinan. Jakarta: RekaCipta

[7] Sugiyono. 2018. Metode Penelitian Kuantitatif, Kualitatif, dan R\&D. Bandung: CV Alfabeta.

[8] Unaradjan, D. D. (2019). Metode penelitian kuantitatif. Penerbit Unika Atma Jaya Jakarta.

[9] Apuke, O. D. (2017). Quantitative research methods: A synopsis approach. Kuwait Chapter of Arabian Journal of Business and Management Review, 33(5471), 1-8.

[10] Sukamolson, S. (2007). Fundamentals of quantitative research. Language Institute Chulalongkorn University, 1, 2-3. 